Tersedia online di: http://ejournal-balitbang.kkp.go.id/index.php/jra

\title{
PERKEMBANGAN SALURAN DAN SISTEM PENCERNAAN PADA LARVA IKAN TUNA SIRIP KUNING, Thunnus albacares (Bonnaterre, 1788)
}

\author{
Gunawan", Jhon Harianto Hutapea, Ananto Setiadi, dan Ketut Mahardika \\ Balai Besar Riset Budidaya Laut dan Penyuluhan Perikanan \\ Jl. Br. Gondol Kec. Gerokgak Kab. Buleleng, Kotak Pos 140, Singaraja 81101, Bali
}

(Naskah diterima: 4 Januari 2019; Revisi final: 14 Februari 2019; Disetujui publikasi: 14 Februari 2019)

\begin{abstract}
ABSTRAK
Penelitian ini bertujuan untuk mengetahui perkembangan saluran dan sistem pencernaan pada larva ikan tuna sirip kuning Thunnus albacores (Bonnaterre, 1788). Sampel larva diambil setiap hari dari larva baru menetas (D-0) sampai D-13, dan selanjutnya dilakukan sampling pada D-15 dan D-20. Semua sampel di foto dengan program ACT-1 dan diproses secara histologi. Hasil pengamatan menunjukkan larva D-0 belum memiliki saluran pencernaan, mulut, dan mata belum terbuka. Pada D-1 saluran pencernaan mulai terbentuk, tetapi masih dalam bentuk tabung lurus. Mulut larva mulai terbuka pada D-2 (45 jam setelah menetas pada suhu air pemeliharaan $28^{\circ} \mathrm{C}$ ). Kuning telur sudah diserap sepenuhnya pada D-3, saluran dan organ pencernaan seperti mulut, esofagus, lambung, ginjal, hati, pankreas, usus, rektum, dan anus sudah terbentuk. Pada D-5 mulai muncul mikro philli pada usus untuk mengabsorbsi nutrisi. Sel-sel penyusun hati, jantung, saluran pencernaan sudah tumbuh dan berkembang menyerupai organ ikan dewasa, ditandai adanya pakan dalam usus. Saluran dan sistem pencernaan telah berdiferensiasi menjadi organ dalam seperti pada ikan dewasa pada hari ke-6 (D-6) dan akan sempurna pada D-20 dengan TL $\pm 2 \mathrm{~cm}$. Berdasarkan perkembangan pencernaan, maka pakan awal berupa rotifer sebaiknya diberikan pada hari ke-2 (43 jam setelah menetas pada suhu air $28^{\circ} \mathrm{C}$ ).
\end{abstract}

\section{KATA KUNCl: larva; pencernaan; Thunnus albacares; tuna}

ABSTRACT: Development of digestive track and system on yellowfin tuna larvae, Thunnus albacares (Bonnaterre, 1788). By: Gunawan, Jhon Harianto Hutapea, Ananto Setiadi, and Ketut Mahardika

\begin{abstract}
The aim of this study was to observe the devel opment of tract and digestive system on yellowfin tuna larvae. Tuna larvae were collected daily from rearing tank at hatching day 0 (D-0) to 13 (D-13). Samples of larvae were selected at D-15 and D-20. All samples were observed under light microscopy, documented and then histologically processed. The results showed that the digestive tract began to form on the larvae at day-1 which was still in the form of a straight tube. The mouth of the larvae starts to open on D-2 (45 hours after hatching at a water temperature of $28^{\circ} \mathrm{C}$ ). At D-3, the larvae's yolk sac was fully absorbed, and its intestine contained a single type of food which was rotifer. The digestive tract and internal organs were formed such as the mouth, esophagus, stomach, kidney, liver, pancreas, intestine, rectum, and anus which indicated that the larvae can eat and digest food. At D-5, microvilli began to develop in the intestine to absorb nutrients. The cells of the liver, heart, digestive tract had grown and evolved to resemble that of mature fish organs characterized by feed in the gut. The tract and digestive system have differentiated into internal organs such as in adult fish at D-6 and fully developed in D-20 with TL $\pm 2 \mathrm{~cm}$. Based on the present finding, it is suggested that the initial feeding of tuna larvae using zooplankton (rotifer) could be done at day two (43 hours) posthatching at a water temperature of $28^{\circ} \mathrm{C}$.
\end{abstract}

KEYWORDS: Iarvae; digestive track; Thunnus; tuna

\section{PENDAHULUAN}

Pembenihan ikan tuna sirip kuning (Thunnus albacares) di hatchery masih dihadapkan oleh beberapa

\footnotetext{
\# Korespondensi: Balai Besar Riset Budidaya Laut dan Penyuluhan Perikanan. Jl. Br. Gondol Kec. Gerokgak Kab. Buleleng, Kotak Pos 140, Singaraja 81101, Bali, Indonesia. Tel. + 6236292278

E-mail: gunawan9505@ gmail.com
}

kendala yang sering menimbulkan kematian massal. Ada tiga faktor utama yang menjadi kendala dalam pembenihan ikan tuna sirip kuning yaitu: 1) tingginya mortalitas pada sepuluh hari pertama yang disebabkan oleh kualitas telur, nutrisi pakan, dan faktor lingkungan seperti cahaya, arus, kandungan oksigen, amoniak, dan nitrit dalam air, serta tekanan osmosis media air pemeliharaan (Kaji, 2003; Patridge, 2009); 2) kematian 
cukup tinggi terjadi pada umur sekitar 20 hari yang disebabkan tingginya tingkat kanibalisme sesama larva (Reglero et al., 2014); 3) pada saat mencapai ukuran juvenil $(T L \pm 2 \mathrm{~cm})$ sering terjadi kematian akibat menabrak dinding atau lompat keluar dari bak pemeliharaan (Kaji, 2003).

Oleh karena itu, penelitian dasar sangat diperlukan mengenai perkembangan organ dalam larva ikan seperti organ yang berhubungan pencernaaan dan pergerakan seperti morfologi larva untuk berenang mencari makan agar bisa hidup dan tumbuh dengan sempurna. Menurut Kato et al. (2004), pengetahuan tentang perubahan perkembangan sistem pencernaan yang terkait dengan asimilasi makanan sangat penting untuk memahami nutrisi yang dibutuhkan oleh larva ikan. Pemahaman tentang sistem pencernaan dan aktivitas enzim pencernaan larva ikan dapat membantu pemilihan pakan yang tepat sesuai dengan kebutuhan larva (Galaviz et al., 2011).

Pengamatan perkembangan awal sistem pencernaan ikan tuna sirip biru, Thunnus thynnus telah dilaporkan oleh Kaji et al. (1996), dan aktivitas enzim pencernaan, serta komposisi asam amino dari juvenil ikan tuna sirip kuning oleh Buentello et al. (2011). Namun, perkembangan sistem pencernaan larva ikan tuna sirip kuning belum ada yang melaporkan. Oleh karena itu, diperlukan penelitian pengamatan perkembangan saluran dan sistem pencernaan larva ikan tuna sirip kuning untuk mendukung keberhasilan perbenihan ikan tuna sirip kuning di Indonesia.

Tujuan dari penelitian ini adalah untuk mengetahui perkembangan saluran dan sistem pencernaan larva ikan tuna sirip kuning (Thunnus albacares) hasil budidaya yang dipelihara di hatchery. Dari hasil penelitian ini diharapkan dapat ditentukan waktu, jenis, dan ukuran pakan awal untuk larva ikan tuna sirip kuning agar pertumbuhan dan kelangsungan hidup meningkat.

\section{BAHAN DAN METODE}

\section{Pemeliharaan Larva}

Penelitian ini dilakukan pada bulan Juli-Agustus 2017 di hatchery ikan tuna sirip kuning dan laboratorium Balai Besar Riset Budidaya Laut dan Penyuluhan Perikanan (BBRBLPP) Gondol, Bali. Telur ikan tuna sirip kuning yang dibuahi (fertile) biasanya mengambang di permukaan air dikumpulkan dari KJA tempat pemeliharaan induk. Telur tersebut Ialu dipelihara dalam bak terbuat dari fiberglass dengan volume $6 \mathrm{~m}^{3}$. Bak dilengkapi dengan aerasi dan sistem pergantian air dan diletakan di lokasi yang diberi atap transparan. Kepadatan tebar telur 20 butir/L.
Pemeliharaan larva diakhiri setelah berumur 20 hari dan umumnya sudah berukuran juvenil (TL $\pm 2 \mathrm{~cm}$ ).

\section{Pengamatan Saluran Pencernaan}

Pengamatan perkembangan saluran dan sistem pencernaan larva ikan tuna sirip kuning dilakukan dengan mengambil larva ikan tuna setiap hari dari umur 0 sampai 13 hari setelah menetas (D-0-D-13) dengan jumlah sampel masing-masing sebanyak 10 ekor, selanjutnya dilakukan sampling larva pada D-15 dan D-20. Sampel larva diamati di bawah steriomikroskop (Nikon tipe SMZ 1000) yang terhubung dengan kamera dan monitor komputer. Pengambilan gambar dilakukan dengan program ACT-1.

\section{Pengamatan Preparat Histologi}

Pengamatan saluran pencernaan dilakukan dengan histologi. Sebanyak 5-20 ekor larva ikan tuna sirip kuning diamati di bawah mikroskop, setelah itu sampel ikan yang sama difiksasi dalam larutan bouin selama 4-6 jam. Preparat histologi berdasarkan Mahardika et al. (2012). Pembuatan preparat dilakukan dengan dehidrasi bertingkat (70\% 80\% 90\% 95\% 100\%, dibersihkan dengan xylol, dan ditanam dalam parafin. Proses embedding dilakukan dalam alat otomatis (automatic tissue processor, Sakura FineTecnhical. C.O. LTD, Tokyo, Japan). Preparat histologi dipotong dengan alat microtome dengan ketebalan $4-5 \mu \mathrm{m}$ dan diwarnai dengan Hematoxylin dan Eosin $(H \& E)$. Pengamatan histologis dilakukan di bawah steriomikroskop (Nikon Eclipse tipe E600) pada pembesaran 10-40x.

\section{HASIL DAN BAHASAN}

\section{Perkembangan Saluran Pencernaan}

Larva yang baru menetas (D-0) mempunyai bentuk tubuh yang transparan, mata dan mulut belum terbuka. Mata dan mulut mulai terbuka pada larva D-2. Pada larva D-0 dan D-1 bagian perut masih terdapat cadangan makanan berupa kuning telur (yolk sac) yang masih cukup besar (Gambar 1), cadangan makanan ini habis pada larva D-2 (Gambar 1).

Pengamatan saluran pencernaan larva D-2 menunjukkan bahwa mulut larva sudah terbuka (45 jam setelah menetas pada suhu air pemeliharaan $28^{\circ} \mathrm{C}$ ). Larva di dalam bak pemeliharaan mulai diberikan pakan alami berupa zooplankton jenis rotifer (B. rotindiformis) dua jam sebelum larva buka mulut (43 jam setelah menetas pada suhu air $28^{\circ} \mathrm{C}$ ). Rotifer diberikan pada larva D-2 dengan pertimbangan bahwa larva dengan kondisi mulut mulai terbuka dengan sempurna dan kuning telur yang telah habis mampu menggunakan rotifer sebagai sumber pakan exogenous. 

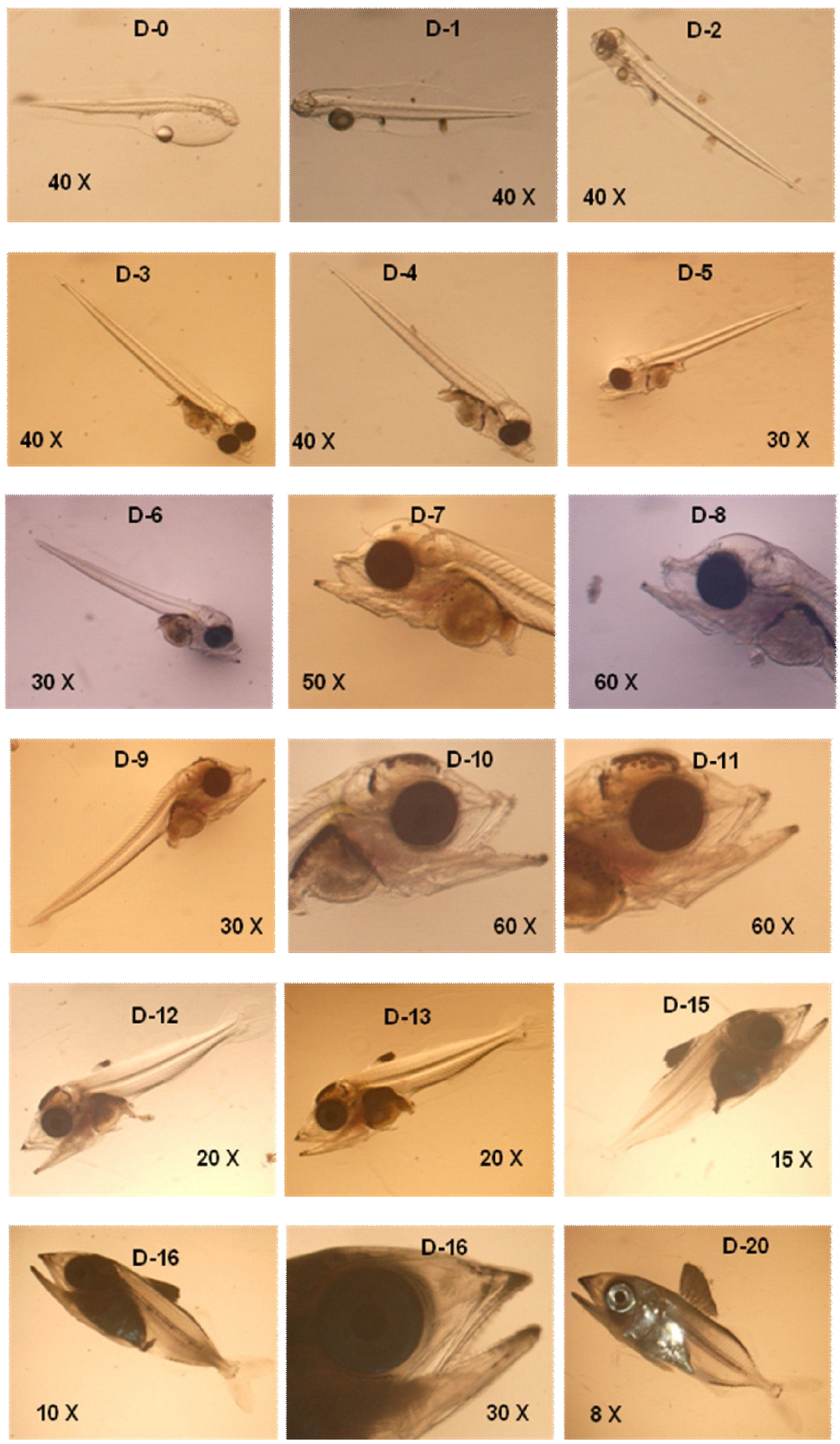

Gambar 1. Perkembangan morfologi larva ikan tuna sirip kuning. Figure 1. M orphological development of yellowfin tuna larvae. 
Larva D-3 terlihat sudah bergerak aktif dalam mencari makanan dari sumber eksogen, hal ini ditandai dengan berkembangnya sirip dada dari hasil pengamatan melalui foto. Pada stadia ini perkembangan organ mata sudah lengkap, mulut sudah terbuka sempurna, kuning telur dan butir minyak sudah habis, dan di dalam perut larva sudah terlihat adanya makanan berupa rotifer. Pada larva baru menetas sampai umur lima hari merupakan masa kritis di mana sering ditemukan kematian larva di permukaan air akibat terjebak tegangan permukaan air. Menurut Kaji et al. (1996), kualitas pakan awal menjadi faktor penentu terjadinya mortalitas pada umur awal larva ikan tuna. Hal tersebut ditunjukkan dari tingkat pertumbuhan yang lambat dari larva ikan tuna pada stadia awal.

Pigmentasi pada bagian atas kepala mulai muncul saat larva D-7, pigmentasi ini semakin terlihat jelas dengan bertambahnya umur larva. Pada D-7 ini juga, organ gigi sudah mulai tumbuh pada rahang atas. Tumbuhnya gigi ini menandakan bahwa larva sudah bisa mengonsumsi pakan dengan ukuran yang lebih besar dari rotifer seperti copepod, naupli Artemia, atau larva ikan yang baru menetas. Di samping itu, gigi tuna sirip kuning yang tajam ini menandakan sifat ikan tuna sirip kuning sebagai karnivora dan sangat rakus makan. Pemberian pakan dengan jumlah yang cukup dan ukuran yang sesuai dengan bukaan mulut akan mengurangi sifat kanibalisme larva ikan tuna sirip kuning. Sifat kanibalisme ini mulai terjadi saat larva umur D-10. Saat larva ikan tumbuh, ada peningkatan dalam keberhasilan menangkap pakan karena ikan yang lebih besar memiliki ukuran bukaan mulut yang lebih besar, dan ukuran pakan terus meningkat sesuai dengan ukuran bukaan mulut larva (DeVries et al., 1998).

Memasuki umur D-12 sudah mulai muncul dorsal fin (sirip punggung) pertama dan pelvic fin (sirip perut) (Gambar 1). Pada sirip ekor mulai terlihat jelas sirisirip tulangnya dan tulang bagian ekor telah mengalami pembelokan. Pada D-12 perkembangan mulut dan gigi larva ikan tuna sudah berkembang sempurna. Sirip ekor sudah berkembang sempurna pada D-15 dengan bentuk sirip ekor yang sudah membelah seperti ikan dewasa, pada stadia ini larva sudah bisa berenang bebas mengelilingi bak pemeliharaan untuk mencari makanan dan untuk mendapatkan suplai oksigen.

Pada D-20 larva ikan tuna sirip kuning sudah metamorphosa menjadi juvenil (secara fisik sudah menyerupai ikan dewasa dengan $T L \pm 2 \mathrm{~cm}$ ) di mana dorsal fin (sirip punggung) pertama maupun sirip punggung kedua sudah tumbuh sempurna dan mulai tumbuh memanjang. Demikian juga dengan pectoral fin (sirip dada) dan pelvic fin (sirip perut) juga sudah tumbuh sempurna, ekor sudah berkembang sempurna dengan pangkal ekor kecil dan kuat sebagai ciri ikan perenang cepat (Gambar 1).

\section{Perkembangan Sistem Pencernaan}

Pada saat larva ikan tuna sirip kuning baru menetas (D-0), saluran pencernaan belum terbentuk. Mulut dan mata belum terbuka, kerongkongan, lambung, usus, rectum, dan anus juga belum terbentuk. Sedangkan organ-organ yang membantu proses pencernaan seperti hati, pankreas, dan ginjal juga belum terlihat (Gambar 2). Hal yang sama juga terjadi pada ikan kakap putih (Atractoscion nobilis) (Galaviz et al., 2011) dan kakap merah (Lutjanus argentimaculatus) (Mahardika et al., 2012). Pada stadia ini kuning telur dan gelembung minyak sebagai sumber makanan masih ada dalam ukuran yang cukup besar. Belum terbentuknya saluran pencernaan pada stadia ini membuat yolk sac berperan besar sebagai sumber nutrisi bagi kelangsungan hidup larva.

Pada larva D-1 saluran pencernaan larva mulai terbentuk, tetapi masih dalam bentuk tabung lurus. Menurut Yufera et al. (2014), lapisan epitel tunggal dibentuk oleh sel-sel kuboid dan columnar pada saluran pencernaan pada stadia ini. Kondisi yang sama juga terjadi pada larva ikan tuna sirip biru Atlantik yang baru menetas. Saluran pencernaan pada larva ikan tuna saat menetas berbentuk lurus sampai ke yolk sac dan berdiferensiasi di daerah usus (Yufera et al., 2014). Mata dan mulut larva ikan tuna sirip kuning $D-1$ belum terbuka, demikian juga dengan lubang anus juga belum terbuka meskipun rektum sudah mulai terbentuk (Gambar 2). Perkembangan saluran pencernaan larva ikan tuna sirip kuning pada D-1 sama dengan yang terjadi pada beberapa jenis spesies ikan laut yang lain pada umur yang sama, seperti ikan kerapu macan Ephinephelus fuscoguttatus (Muzaki et al., 2012), kerapu bebek Cromileptes altivelis (Andriyanto, 2011), kakap putih Atractoscion nobilis (Galaviz et al., 2011), yellow catfish Pelteobagrus fulvidraco (Yang et al., 2010), dan kakap merah Lutjanus argentimaculatus (Mahardika et al., 2012).

Menurut Kolkovski (2001), saat baru menetas saluran pencernaan berbentuk tabung lurus sampai mulut. Saluran pencernaan ini tidak berubah sampai mulut terbuka dan kuning telur terserap habis. Selanjutnya, saluran pencernaan akan berdiferensiasi menjadi buccopharynx, foregut, midgut, dan hindgut.

Mulut dan mata sudah terbuka saat larva memasuki umur dua hari (D-2), saluran pencernaan masih berbentuk tabung lurus dari esophagus (kerongkongan) sampai anus. Esophagus (kerongkongan) mulai 


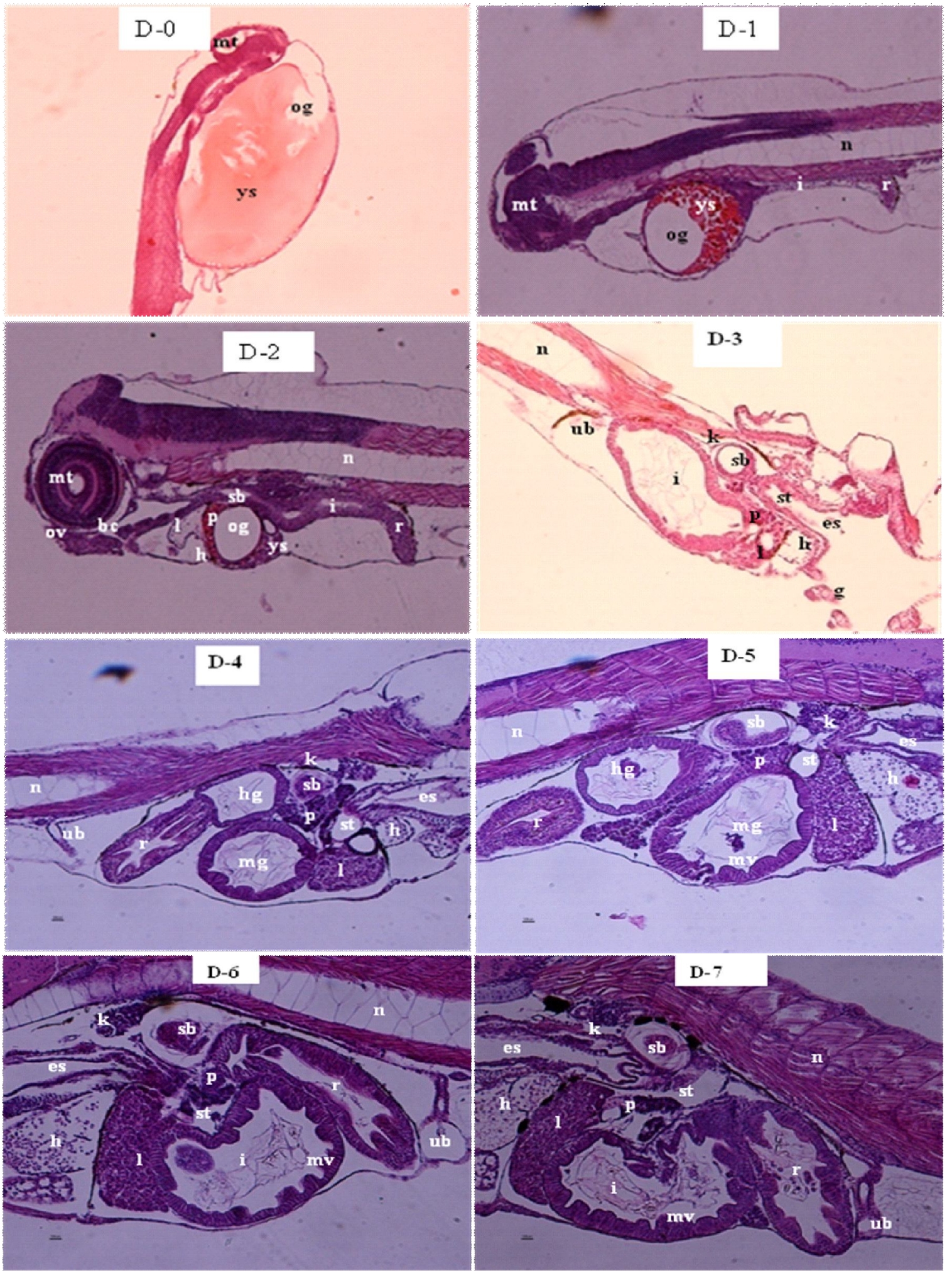

Keterangan (Note): og: butiran minyak (oil globule), mt: mata (eye), i: usus (intestine), r: rectum, es: kerongkongan (esofagus), an: anus, l: hati (liver), p: pankreas, hg: hindgut, ov: oral valve, st: lambung (stomach), ys: kuning telur (yolk sac), n: tulang (notochord), bc: rongga mulut (buccal cavity), sb: gelembung renang (swim bladder), h: jantung (heart), k: ginjal (kidney), mg: midgut, mv: micro villi, ub: kandung kemih (urine bladder), g: insang (gill)

Gambar 2. Perkembangan saluran pencernaan larva ikan tuna sirip kuning.

Figure 2. Digestive track development of yellow fin tuna larvae. 

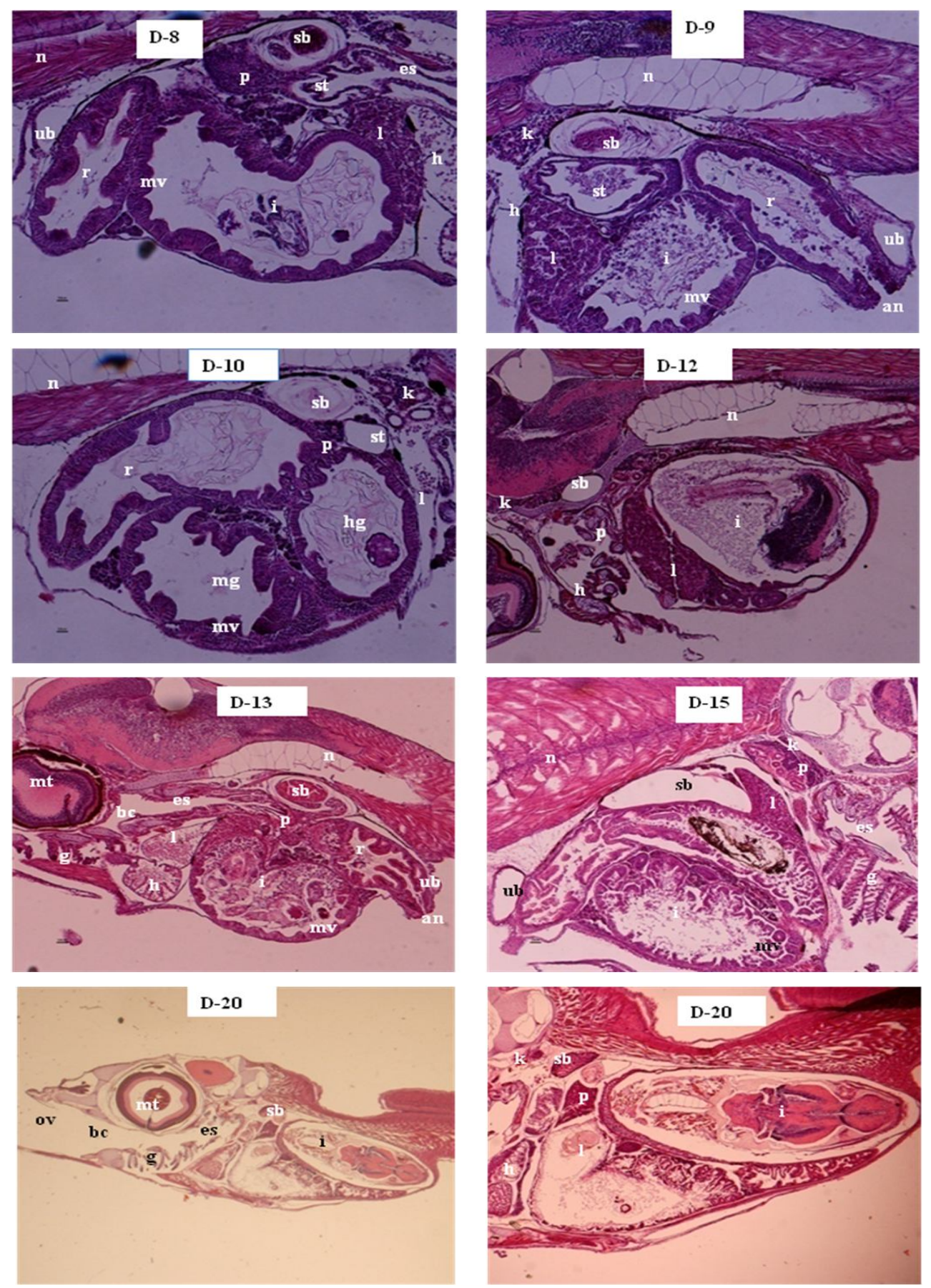

Gambar 2. Lanjutan.

Figure 2. Continued.

skuamosa mulai terbentuk. Usus primordial dari larva D-2 ini dibatasi oleh satu lapisan sel kolumnar. Swim bladder (gelembung renang) sudah terbentuk pada larva D-2 yang memungkinkan larva dapat turun naik dalam air pemeliharaan, demikian juga organ ginjal, pancreas, dan hati juga sudah terbentuk. Terbentuknya gelembung renang pada ikan tuna sirip kuning sedikit lebih cepat dibandingkan dengan terbentuknya gelembung renang pada ikan kakap putih Atractoscion nobilis yaitu pada saat larva umur D-3 (Galaviz et al., 2011).

Menurut Yufera et al. (2014), perkembangan sistem pencernaan larva ikan tuna sirip biru atlantik pertama terjadi dengan pembukaan dari kedua mulut dan anus pada D-2. Mulut dibedakan ke dalam rahang bagian atas dan bawah, selanjutnya rongga buccal, kerongkongan, dan usus juga terdeteksi pada larva D-2. Pada fase ini, rongga bukal pada larva ikan tuna 
sirip biru atlantik ditutupi oleh lapisan tunggal dari sel epitel. Pada fase ini hati muncul sebagai jaringan basophilic yang melekat pada yolk sac. Sistem pencernaan dan organ pencernaan juga sudah mulai terbentuk pada larva D-2 ikan kerapu macan Ephinephelus fuscogutatus (Muzaki et al., 2012), kerapu bebek Cromileptis altivelis (Andriyanto, 2011), yellow catfish Pelteobagrus fulvidraco (Yang et al., 2010), dan ikan kakap merah Lutjanus argentimaculatus (Mahardika et al., 2012).

Pada larva ikan tuna sirip kuning D-3 yolk sac sudah diserap sepenuhnya oleh larva, dan di dalam usus sudah terdapat makanan berupa rotifer. Pada stadia ini saluran dan organ pencernaan sudah berfungsi sepenuhnya seperti mulut, esofagus, lambung, ginjal, hati, pankreas, usus, rektum, dan anus; sehingga larva pada stadia ini sudah bisa menelan, menyerap, dan mengasimilasi pakan yang pertama kali di dapat dari sumber eksogen saat yolk sac sudah benar-benar habis diserap. Jantung sudah terlihat jelas, gelembung renang juga sudah semakin membesar. Sel-sel epitel skuamosa berlapis terbentuk di esofagus pada larva ikan tuna sirip kuning umur tiga hari ini. Usus sudah melipat dan juga sudah terpisah dari rektum, urine bladder (kandung kemih), yang berada di belakang rektum juga terbentuk. Urine bladder ini juga bisa dipakai sebagai indikator kualitas air dalam media pemeliharaan larva, bila di dalam urine bladder terdapat kotoran seperti berbentuk kristal biasanya kondisi kualitas air dalam media pemeliharaan larva kurang baik. Lambung pada larva ikan kakap merah Lutjanus argentimaculatus baru muncul saat larva umur lima hari (Mahardika et al., 2012), larva ikan kerapu bebek Cromileptis altivelis pada hari kedua (Andriyanto, 2011) dan larva kerapu macan Epinephelus fuscogutatus pada hari ketiga (Muzaki et al., 2012).

Larva mulai umur empat hari (D-4) bentuk usus sudah melingkar dan dibagi menjadi dua bagian, usus yang dekat dengan lambung disebut midgut sedangkan yang dibelakang yang langsung berhubungan dengan rektum disebut hindgut. Pada tahap ini, kerongkongan, lambung, usus, rektum, hati, dan pankreas sudah terlihat lebih jelas. Pada larva D-5 mulai muncul mikro philli pada usus untuk mengabsorbsi nutrisi. Ukuran hati dan jantung sudah lebih besar, usus juga lebih besar dengan jumlah pakan yang terdapat di dalamnya lebih banyak.

Pada larva ikan tuna sirip kuning D-6 saluran pencernaan mulai dari kerongkongan, lambung, usus, rektum, dan anus sudah terlihat dengan jelas. Ukuran jantung dan hati lebih membesar, demikian juga dengan organ yang lain seperti ginjal, swim bladder, pankreas, dan urinebladder juga semakin berkembang.
Saluran dan sistem pencernaan larva ikan tuna sirip kuning pada D-6 semua sudah tersedia dan selanjutnya adalah proses penyempurnaan. Pada D-20 saluran dan sistem pencernaan sudah sempurna dan larva sudah metamorphosa menjadi juvenil (secara fisik sudah menyerupai ikan dewasa dengan $T L \pm 2 \mathrm{~cm}$ ).

\section{KESIMPULAN}

Larva ikan tuna sudah mulai makan pakan luar (eksogen) pada D-3. Saluran dan sistem pencernaan telah berdiferensiasi menjadi organ dalam seperti pada ikan dewasa pada hari ke-6 (D-6) dan akan sempurna pada $\mathrm{D}-20$ dengan $\mathrm{TL} \pm 2 \mathrm{~cm}$.

\section{UCAPAN TERIMA KASIH}

Ucapan terima kasih kepada Pusat Riset Perikanan, Badan Riset dan Sumberdaya Manusia Kelautan dan Perikanan, Kementerian Kelautan dan Perikanan (KKP) yang telah membiayai penelitian ini melalui DIPA BBRBLPP Gondol Tahun Anggaran 2017. Ucapan terima kasih kepada rekan teknisi yang telah membantu dalam pelaksanaan penelitian ini, Mujimin, Slamet Hariyadi, Nengah Mupu, M. Arif, Syahrodi, dan Jafar Shadiq.

\section{DAFTAR ACUAN}

Andriyanto, W. (2011). Studies on the ontogeny of the digestive system and selected enzyme activity during early life stages of humpback grouper (Cromileptes altivelis) (Valenciennes, 1828). Thesis submitted in fulfillment of the requirement for the Degree of Master of Science in the Institute of Tropical Aquaculture. University Malaysia Terengganu.

Buentello, J.A., Pohlenz, C., Margulies, D., Scholey, V.P., Wexler, J.B., Ramírez, D.T., Neill, W.H., Baltazar, P.H., \& Gatlin, D.M. (2011). A preliminary study of digestive enzyme activities and amino acid composition of early juvenile yellowfin tuna (Thunnus albacares). Journal Aquaculture, 312, 205211.

DeVries, D.R., Bermigan, M.T., \& Stein, R.A. (1998). Prey selection by larval fishes as influenced by available zooplankton and gape limitation. Transactions of the American Fisheries Society, 127, 10401050.

Galaviz, M.A., García-Gasca, A., Drawbridge, M., Álvarez-González, C.A., \& López, L.M. (2011). Ontogeny of the digestive tract and enzymatic activity in white seabass, Atractoscion nobilis, larvae. Journal Aquaculture, 318, 162-168.

Kaji, T., Tanaka, M., Takahashi, Y., Oka, M., \& Ishibashi, N. (1996). Preliminary observations on development of Pacific bluefin tuna Thunnus thynnus (Scombridae) larvae reared in the laboratory, with 
special reference to the digestive system. Marine and Freshwater Research, 47(2), 261-269.

Kaji, T. (2003). Bluefin tuna larval rearing and development: State of the art. p. 84-89. In Bridges, C.R., García, A., \& Gordin, H. (Eds.). Domestication of the bluefin tuna Thunnus thynnus. Zaragoza: Ciheam, p. 85-89.

Kato, K, Ishimaru, K., Sawada, Y., Mutsuro, J., Miyashita, S., Murata, O., \& Kumai, H. (2004). Ontogeny of digestive and immune system organs of larval and juvenile kelp grouper Epinephelus bruneus reared in the laboratory. Fisheries Science, 70, 1061-1069.

Kolkovski, S. (2001). Digestive enzymes in fish larvae and juveniles- Implications and applications to formulated diets. Journal Aquaculture, 200, 181201.

Mahardika, K., Mastuti, I., Melianawati, R., \& Zafran. (2012). Histological study on internal organs development of mangrove snapper, Lutjanus argentimaculatus larvae. Indonesian Aquaculture Journal, 7(2), 133-138.

Muzaki, A., Mahardika, K., Mastuti, I., Andriyanto, W., Asih, Y.N., \& Wardana, I.K. (2012). The diges- tive track development of the tiger grouper Ephinephelus fuscogutatus larvae treated with thyroxine hormone. Indonesian Aquaculture Journal, $7(2), 115-122$.

Patridge, G. (2009). The international experience. In Patridge, $G(E d$.$) . Hatchery production of yellow-$ fin tuna. Melbourne, Australia: International Specialised Skills Institute Inc., p. 11-25.

Reglero, P., Ortega, A., Blanco, E., Fiksen, Ø., Viguri, F.J., De la Gándara, F., Seoka, M., \& Folkvord, A. (2014). Size-related differences in growth and survival in piscivorous fish larvae fed different prey types. Journal Aquaculture, 433, 94-101.

Yang, R., Xie, C., Fan, Q., Gao, C., \& Fang, L. (2010). Ontogeny of the digestive tract in yellow catfish Pelteobagrus fulvidraco larvae. Journal Aquaculture, 302, 112-123.

Yufera, M., Ortiz-Delgado, J.B., Hoffman, T., Siguero, I., Urup, B., \& Sarasquete, C. (2014). Organogenesis of digestive system, visual system and other structures in Atlantic bluefintuna (Thunnus thynnus) larvae reared with copepods in mesocosm system. Journal Aquaculture, 426-427, 126-137. 